\title{
Recorregut de recerca geològica i mineralògica per la Vall de Ribes (comarca del Ripollès): des de Ribes de Freser, a Rialb, Vilamanya, a Queralbs i a Planoles
}

Josep Maria Mata-Perelló

Joaquim Sanz Balagué

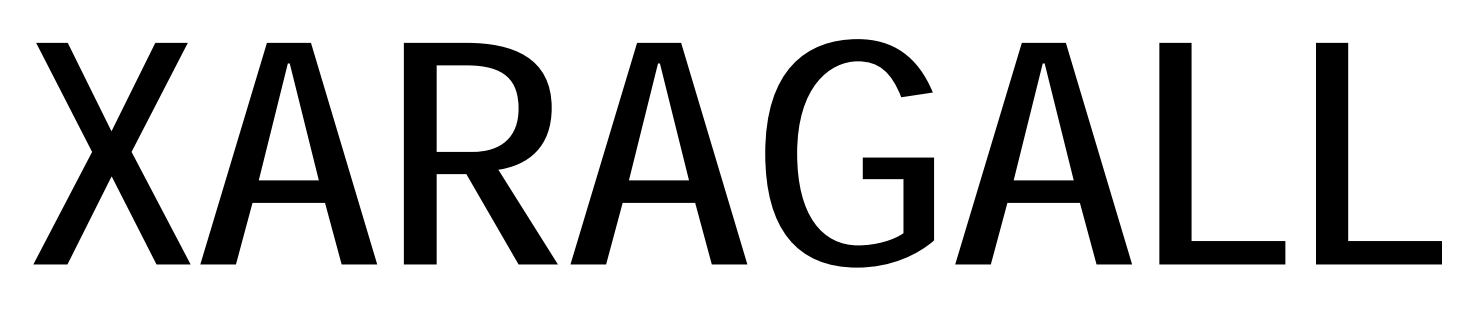

REVISTA DE CIÈNCIES DE LA CATALUNYA CENTRAL n. 7

JULIOL 2014 


\title{
RECORREGUT DE RECERCA GEOLÒGICA I MINERALÒGICA PER LA VALL DE RIBES (COMARCA DEL RIPOLLÈS): DES DE RIBES DE FRESER, A RIALB, VILAMANYA, A QUERALBS I A PLANOLES
}

\author{
Josep Maria Mata-Perelló \\ Museu de geologia Valentí Masachs, Escola Politècnica Superior d'Enginyeria de Manresa \\ (EPSEM), Universitat Politècnica de Catalunya · BarcelonaTech (UPC), 08272 Manresa, Spain
}

Joaquim Sanz Balagué

Departament d'Enginyeria Minera i Recursos Naturals (EMRN), Escola Politècnica Superior d'Enginyeria de Manresa (EPSEM), Universitat Politècnica de Catalunya - BarcelonaTech (UPC), 08272 Manresa, Spain

Paraules clau: Sistema Pirinenc; Pirineus Orientals; Geologia; Mineralogia

\section{Resum}

Itinerari realitzat el 2 de juny de 2013. En aquesta ocasió, el recorregut de l'itinerari discorrerà en la totalitat pel Sistema Pirinenc, i més concretament pel sector dels Pirineus Orientals. Dintre d'aquests, deambularà per dos dels seus sectors més representatius: en concret per la zona dels anomenats Apilaments Antiformes del Freser, i també per la Zona Axial, pròpiament dita.

Així, el recorregut s'iniciarà dintre dels Apilaments Antiformes del Freser, pels voltants del poble de Ribes de Freser. Finalment, els darrers trams del recorregut de l'itinerari, ja s'afectaran per la Zona Axial, en la qual clourà el recorregut, en arribar a la Mina Saragossa, del municipi de Queralt. I finalment, en arribar al Pla de les Cabanes (Planoles), per on clourà el recorregut. També cal dir, per d'altra banda, que la totalitat del recorregut, del present itinerari, es desenvoluparà per dintre de la superfície ocupada per la comarca del Ripollès, la qual pertany a la Regió de Vic. I més concretament, es desenvoluparà per la coneguda Vall de Ribes, constituïda per les vall del Rigard i del Freser. 


\section{Objectius fonamentals}

Els objectius fonamentals que es pretenen aconseguir en aquest itinerari geològic $\mathrm{i}$ mineralògic, són els següents:

1. Observació i estudi dels afloraments del Sistema Pirinenc, tant dels que corresponen ala Apilaments Antiformes del Freser, o com els de la Zona Axial, els quals anirem trobant a diferents indrets al llarg de tot el recorregut de l'itinerari.

2. Observació i estudi dels materials paleozoics (fonamentalment del Cambro-Ordovicià i de I'Ordovicià), que constitueixen tant els afloraments dels Apilaments Antiformes del Freser, com els de la Zona Axial. Aquests materials els tallarem pels voltants de Ribes de Freser, i entre aquesta població i la de Queralbs. I també entre aquesta i el Pla de les Cabanes (del terme de Planoles) a la Vall del Rigard.

3. Estudi i descripció de les relacions i els contactes existents entre les tres unitats acabades d'esmentar al paràgrafs anteriors, i també entre els materials que les constitueixen. Així, ens referirem al denominat encavalcament de Ribes - Camprodon. el qual constitueix el límit septentrional dels Apilaments Antiformes de Ribes.

4. Observació i reconeixement dels materials volcànics, si s'escau, que es troben entre els afloraments de l'Ordovicià (dintre dels Apilaments Antiformes de Ribes). Aquests afloraments es troben constituïts per riolites i granòfirs (els denominats "granòfirs de Ribes").

5. Estudi i descripció de diferents mineralitzacions, que anirem veient al llarg de tot el recorregut, com les següents:

5A) de les mineralitzacions filonianes d'antimoni i d'arsènic, situades als termes de Ribes de Freser i Queralbs, entre molts altres indrets de la comarca del Ripollès. Encaixen sempre entre els materials de l'Ordovicià.

5B) de les mineralitzacions ferruginoses relacionades amb l'alteració de pirites, situades prop de Vilamanya, entre els materials de I'Ordovicià.

5C) Observació de les mineralitzacions filonianes de coure, situades al terme de Planoles, al Pla de les Cabanes. Com les anteriors, encaixen sempre entre els materials de I'Ordovicià.

6. Observació de diferents explotacions mineres, relacionades amb les mineralitzacions acabades d'esmentar.

7. Observació del diferents elements, relacionats amb el patrimoni geològic i miner, que anirem trobant al llarg del recorregut. 


\section{Antecedents}

$\mathrm{Hi}$ ha alguns antecedents, relatius a itineraris geològics i mineralògics, el quals discorren per indrets propers al present. Entre aquests, farem esment de diversos treballs nostres, com els següents: Mata-Perelló (1995, 1996a, 1996b, 1996c, 1997a, 1997b, 1998, 2007, 2011a, 2011b). I molt més recentment: Mata-Perelló (2013a i 2013b).

Tanmateix farem esment de dos treballs més, on hi ha itineraris coincidents parcialment amb el present. Es tracta de: Mata-Perelló i Font Soldevila (1995), i de Mata-Perelló i Sanz Balagué (1991).

Pel que fa a les mineralitzacions que veurem en aquest itinerari, cal dir que ja estat prèviament descrites per nosaltres en un altre treball (d'àmbit general referit al conjunt de Catalunya), al qual ens remetin. Es tracta de Mata-Perelló (1991).

Per d'altra banda, en canvi, farem esment de diversos treballs, de caràcter geològic general i regional, com són els següents: Guimerà et altri (1992) i Riba et altri (1976). Tanmateix, i pel que fa a les monografies regionals, farem esment dels treballs: IGME (1991 i 1994).

Tots aquests treballs, figuren convenientment referenciats, per estricte ordre alfabètic, dintre de I'apartat dedicat a les REFERÈNCIES BIBLIOGRÀFIQUES, al qual ens remetin.

\section{Recorregut de l'itinerari}

El recorregut de l'itinerari, s'iniciarà a la població de Ribes de Freser, per on es farà una primera aturada. Després des d'ella, el recorregut farà una fillola, i es dirigirà cap a les immediacions de la població de Campelles (seguint inicialment la carretera local GiV - 4011) per tal d'anar cap a les Mines de Sant Antoni, per on es faran dues noves aturades.

Posteriorment, el recorregut de l'itinerari, retornarà a la població de Ribes de Freser, des d'on es continuarà cap el Nord, seguint la carretera local GiV - 5217). En trobar el trencall del poblet de Vilamanya, ens caldrà agafar-lo. Poc abans d'arribar a aquest poble, farem una nova aturada a la Mina Rèplica.

Posteriorment, des del darrer poble esmentat, ens caldrà anar cap a l'antiga Mina Saragossa, on es farà una nova aturada. Finalment, ens caldrà agafar la pista de terra que condueix cap a Planoles, però en trobar la carretera que condueix cap al Pla de les Cabanes, ens caldrà agafar-la. En arribar a aquest indret farem la darrera aturada d'aquest itinerari. 


\section{Advertiments previs}

Com en altres recorreguts de RECERCA GEOLÒGICA I MINERALÒGICA ..., semblants al present, si es disposa del temps suficient, poden efectuar-se passant per totes les parades i filloles indicades al present guió. En cas contrari, recomanem prescindir de les anomenades PARADES CONDICIONALS.

Cal dir també, que en aquest itinerari ens trobarem devent de tres trams de camins forestals en molt mal estat de conservació; per la qual cosa serà molt millor transitar a peu per ells. En aquest itinerari, hi ha alguns trams de terra, com el que es dirigeix des de Vilamanya a la Mina Saragossa. I després cap el Pla de les Barraques, del terme de Planoles.

En qualsevol cas, cal tenir sempre una cura molt especial de respecte a la natura, al llarg de tot el recorregut de l'itinerari.

\section{Descripció de l'itinerari}

Com de costum, estructurarem el recorregut de l'itinerari en una sèrie de PARADES (o d'ESTACIONS), que tot seguit anirem veient. En cadascuna d'aquestes aturades farem un breu comentari (geològic o mineralògic, segons s'escaigui). Per d'altra banda, en cada cas indicarem, entre parèntesi, el full topogràfic on es troba l'aturada.

Per d'altra banda, en cadascuna de les parades, indicarem entre parèntesi el número del "Mapa Topográfico", a escala 1:50.000, on es troba situada la parada considerada. Finalment, cal dir que el recorregut de l'itinerari s'inclourà dintre dels següents fulls: 217 (dit de Puigcerdà), 218 (o de Molló), 255 (dit de la Pobla de Lillet) i 256 (o de Ripoll).

Així doncs, la relació general ordenada de les parades que constitueixen aquest itinerari, és la següent:

\subsection{Parada 1. CONDICIONAL. ESGLÈSIA DE RIBES DE FRESER, (terme municipal de Ribes de Freser, comarca del Ripollès). (Full 256).}

El recorregut de l'itinerari el començarem al bell mig de la població de Ribes de Freser, concretament al costat de l'Església Parroquial, on hi ha uns plafons de caire geològic, al costat dret de l'entrada principal.

Ribes de Freser es troba a la Vall de Ribes, a la comarca del Ripollès, entre afloraments dels materials paleozoics de I'Ordovicià. Així, es situa prop del denominat Encavalcament de Ribes - Camprodon, el qual posa en contacte els Apilaments Antiformes de Ribes (situats al Sud) i els Apilaments Antiformes de la Zona Axial Pirinenca (situats al Nord).

En aquest indret hi ha uns panells explicatius dels granòfirs de Ribes de Freser. Es tracta d'unes roques subvolcàniques. De composició leucogranítica, semblant a les de les riolites, riques en QUARS i en feldspats potàssics (ORTOSA), amb presencia de plagiòclasis sòdiques (ALBITA) i de BIOTITA. (fotografies 1 i 2). 


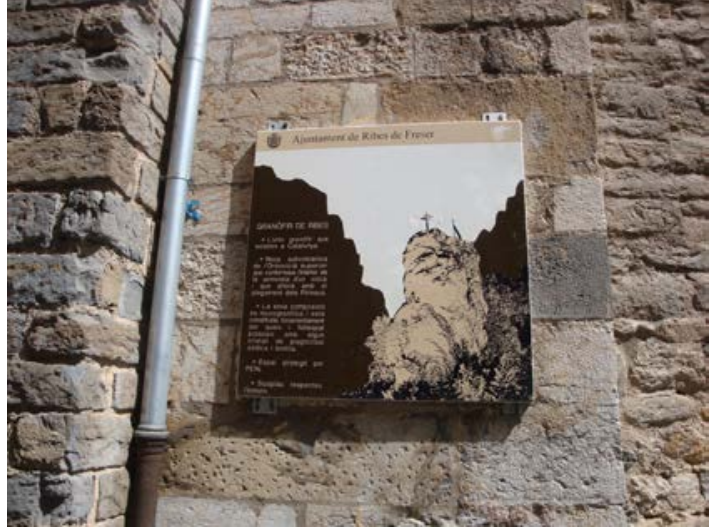

Fotografia 1. Plafó explicatiu dels granòfirs. Façana de I'església de Ribes. Terme de Ribes de Freser

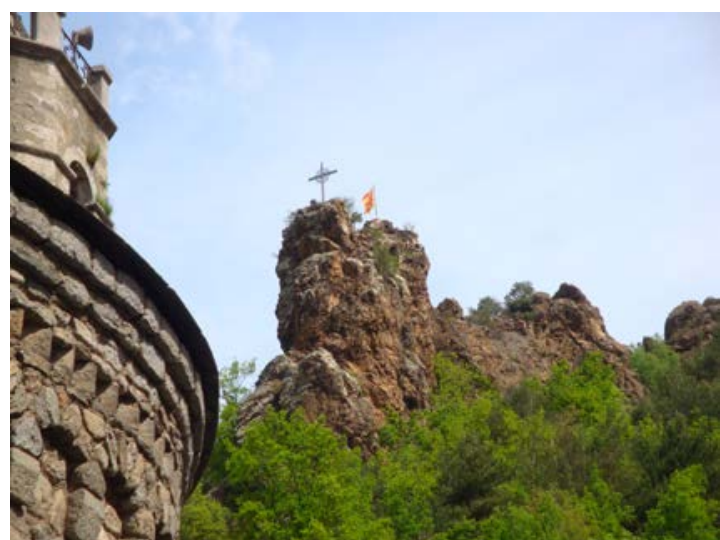

Fotografia 2. Turó del Castell de Sant Pere, aflorament de granòfirs. Terme de Ribes de Freser

\subsection{Parada 2. TURÓ DE SANT ANTONI, (terme municipal de Ribes de Freser, comarca del Ripollès). (Full 256).}

Després de fer l'aturada anterior, a la població de Ribes de Freser, situada al peu de la carretera nacional N-152 / N - 260, ens caldrà anar cap a l'Estació, per tal d'agafar la carretera local que es dirigeix cap a Campelles, la GiV-4011, amb la finalitat de fer una fillola en arribar al collet de la Casassa, d'on surt un camí per la dreta, el qual ens conduirà fins a l'Ermita de Sant Antoni. Prop d'aquest indret, es farà la present aturada. Concretament al Turó de Sant Antoni. Així, des de la parada anterior, haurem efectuat un recorregut proper als $6 \mathrm{Km}$, aproximadament, des de l'inici del recorregut

A partir del seu inici el recorregut, s' efectua entre els materials esquistosos i pissarrencs de I'Ordovicià, els quals situats a la zona d'Apilaments Antiformes del Freser. Entre aquests materials, cal fer esment de la presència del granòfir de Ribes, el qual es troba prop de l'ermita de Sant Antoni, al Nord de la mateixa. I al costat de l'ermita, és on es troba el Turo de Sant Antoni, on fem aquesta aturada.

En aquest indret, hi ha un interessant aflorament de les roques que hem esmentat a l'aturada anterior, els granòfirs de Ribes de Freser, dels quals ja n'hem parlat a la PARADA 1. Es tracta de roques subvolcàniques leucogranítiques. (fotografia 3).

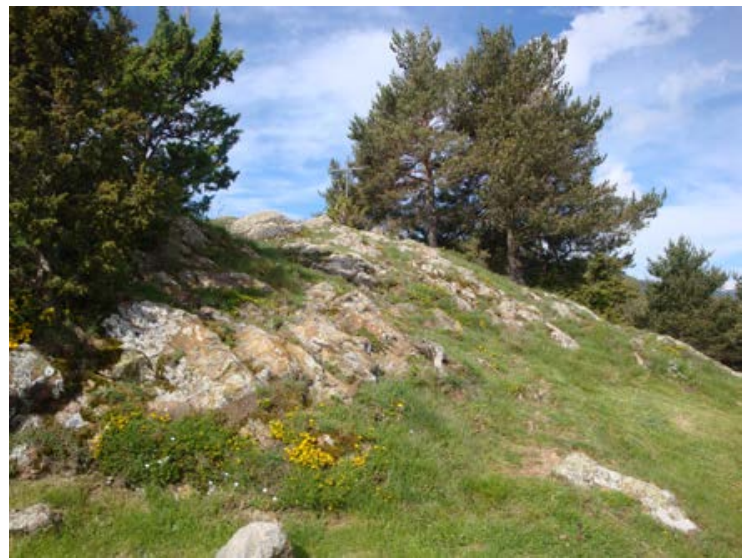

Fotografia 3. Turó de Sant Antoni, aflorament de granòfirs. Terme de Ribes de Freser 


\subsection{Parada 3. MINES DE SANT ANTONI, (terme municipal de Ribes de Freser, comarca del Ripollès). (Full 256).}

Després de fer l'aturada anterior, cal fer un breu recorregut a peu, anant cap a ponent de la parada anterior, seguint un corriolet paral-lel a la carretereta que ens ha dut fins aquí. A menys de $0^{\prime} 2 \mathrm{Km}$, trobarem unes antigues mines, per on farem una nova aturada. Es tracta de les Mines de Sant Antoni.

En aquest indret, hi ha una mineralització filoniana, la qual es troba encaixada entre els esquistos de I'Ordovicià. Entre els minerals primaris presents, cal fer esment dels següents: AESENOPIRITA, BETHIERITA (indicis), CALCOPIRITA, ESTIBINA (és el mineral més abundant), GALENA, JAMESONITA, PIRITA, TETRAEDRITA, CALCITA i QUARS.

Entre els minerals d'alteració, cal fer esment dels següents: CERVANTINITA, GOETHITA (terrosa i limonítica), HEMATITES, VALENTINITA, ATZURITA (indicis), MALAQUITA i GUIX. També cal fer esment de la presencia de PIROLUSITA (dendrítica).

En aquest indret, es van realitzar diverses explotacions mineres, generalment poc importants. A I'actualitat es troben força enrunades, i es molt dificultós trobar els filons. (fotografia 4).

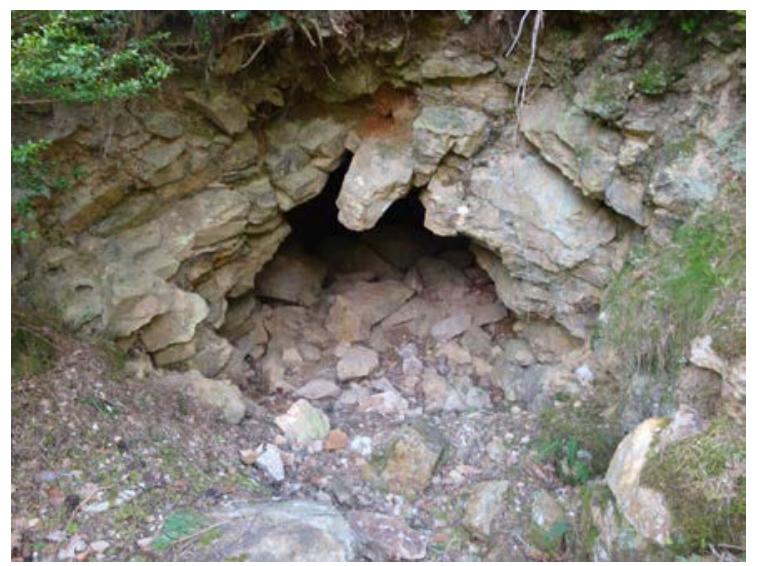

Fotografia 4. Una de les antigues explotacions de les Mines de Sant Antoni. Terme de Ribes de Freser

\subsection{Parada 4 - CONDICIONAL. MINES DE RIALB, (Rialb, terme municipal de Queralbs, comarca del Ripollès). (Full 218).}

Després de realitzar l'aturada anterior, cal retornar cap la població de Ribes de Freser. Des d'aquí, ens caldrà agafar la carretera local GiV-5217, la qual es dirigeix cap a Rialb. En arribarhi, haurem de continuar a peu, per tal d'arribar al paratge on hi ha les Coves de Can Damià. En aquest indret farem la primera aturada, a uns $3 \mathrm{Km}$ de Ribes de Freser i a uns $10 \mathrm{Km}$ de la parada anterior.

En un principi, aquest recorregut, s' haurà efectuat entre afloraments dels nivells esquistosos de I'Ordovicià, entre els quals es troben freqüents intercalacions de calcàries i de dolomies. Aquests materials s'inclouen en la zona dels Apilaments Antiformes del Freser, per on ha deambulat el recorregut de l'itinerari des de la parada anterior, fins poc després de sobrepassar Ribes de Freser; doncs en trobar el camí-carretera de Batet, hem sobrepassat l'encavalcament de Ribes-Camprodon, que aquí posa en contacte els materials abans esmentats dels 
Apilaments Antiformes de Ribes, amb el també paleozoics de I'Ordovicià de la Zona Axial, on ara ens trobem situats. En aquest indret apareixen uns trams carbonatats del Devonià.

Precisament sobre aquests trams s' han originat les formacions kàrstiques que han donat lloc a les coves de Can Damià, les quals es troben prop d'on ara estem situats. Per d'altra banda, en aquest indret hi ha una mineralització filoniana que encaixa entre les esmentades calcaries. Entre els minerals presents, cal fer esment dels següents: ARSENOPIRITA, CALCOPIRITA, GALENA, PIRITA, així com diversos minerals d'alteració.

Finalment, cal dir que aquesta mineralització ha estat explotada en una antiga mineta, situada molt prop de la via del Cremallera.

\subsection{Parada 5. MINES DE VILAMANYA. MINA DE "LA REPLICA", (Vilamanya, terme municipal de Queralbs, comarca del Ripollès). (Full 218).}

Després d'efectuar la parada anterior, cal retornar a la carretera GiV-5217. En trobar-la, ens haurem de dirigir cap el Nord, fins trobar per la dreta un camí-carretera, el qual es dirigeix cap a la petita població de Vilamanya. Poc abans d'arribar a aquest poblet, en una corba de la carretera, es troba una petita mineta, on efectuarem la present aturada, després d'un recorregut proper als $6 \mathrm{Km}$, des de la parada anterior.

En un principi, aquest recorregut, s' haurà efectuat entre afloraments dels nivells esquistosos de I'Ordovicià, entre els quals es troben freqüents intercalacions de calcàries i de dolomies. Aquests materials s'inclouen en la zona dels Apilaments Antiformes de la Zona Axial, on ara ens trobem situats.

En arribar a aquest indret, ens trobem davant d'una petita explotació relacionada amb els esquistos paleozoics de l'Ordovicià, sovint piritosos. Així, aquí, per oxidació de la PIRITA, ens trobem amb la presència de GOETHITA (molt limonítica i terrosa), i d'HEMATITES (també molt terròs). Aquí es van intentar explotar els òxids de ferro, sense cap mena d'èxit. L'explotació consisteix en una petita galeria, oberta entre els esquits, en la qual hi ha una abundant presència de filtracions d'aigües, enriquides amb els òxids de ferro abans esmentats. (fotografia 5).

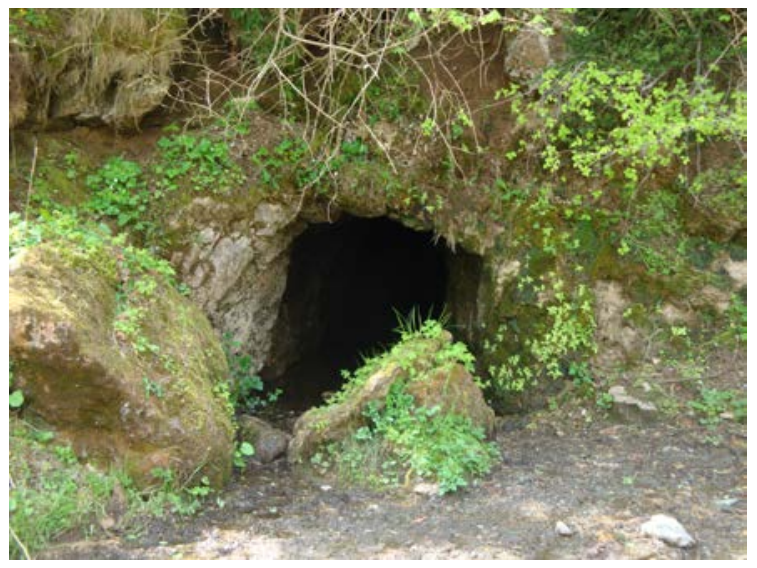

Fotografia 5. Bocamina inferior de "la Rèplica". Vilamanya, terme de Queralbs

Finalment, cal dir que al costat de l'entrada de la mina, hi ha un plafó força interessant, explicant les característiques de la mateixa. 


\subsection{Parada 6. LABORS INFERIORS DE LA MINA SARAGOSSA, (terme municipal de Queralbs, comarca del Ripollès). (Full 218).}

Des de la parada anterior, cal continuar per la pista-carretera que es dirigeix cap al proper poble de Vilamanya. Després de sobrepassar-lo, cal continuar cap al NW, per aquest mateix camí, que ara es troba en no gaire bones condicions. Seguint per ell, ens caldrà sobrepassar el camí que se'n va cap a Planoles. Finalment, s'arribarà a la Mina Saragossa, on cal efectuar les presents aturades. Així, s' hauran recorregut des de la parada anterior, uns $4 \mathrm{Km}$. La primera d'aquestes aturades la farem a un nivell inferior de la mina, situada per sobre del camí carretera.

Tot aquest recorregut, s'haurà efectuat entre afloraments dels nivells esquistosos de I'Ordovicià, entre els quals es troben freqüents intercalacions de calcàries i de dolomies. Aquests materials s' inclouen dintre de la denominada Zona Axial, en la qual hem entrat en fer el recorregut cap a la parada anterior.

En aquest cas, després d'entrar a la bocamina situada a la bora del camí, després de recórrer una galeria de prop de 150 metres, ens trobarem amb unes interessants formacions kàrstiques. Aquestes són d'una gran bellesa. Entre aquestes formacions es troben bones cristal.litzacions d'ARAGONITA. (fotografia 6).

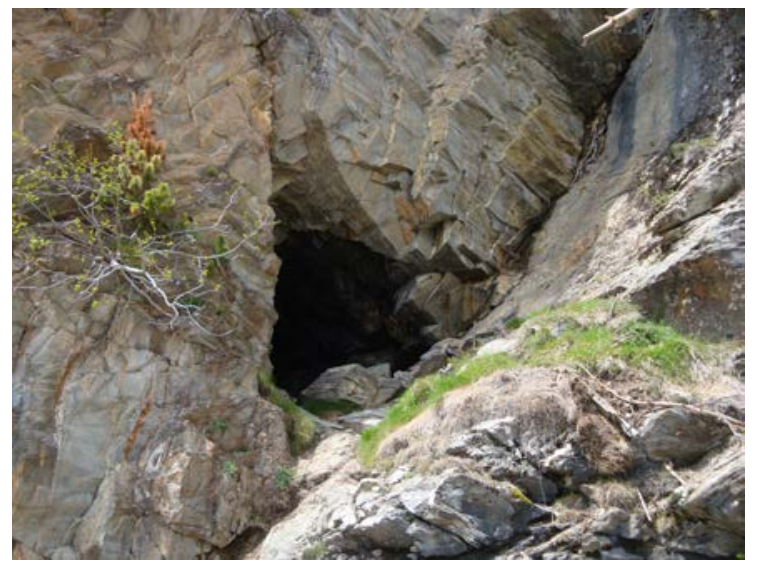

Fotografia 6. Bocamina inferior de Mina Saragossa. Aflorament dels calcosquists de I'Ordovicià.

Vilamanya, terme de Queralbs

\subsection{Parada 7. MINA SARAGOSSA, (terme municipal de Queralbs, comarca del Ripollès). (Full 218).}

Des de la parada anterior, cal continuar a peu per la pista-carretera, remuntant un fort desnivell. Després ens caldrà pujar a peu com a la boca superior de la Mina Saragossa, on cal efectuar la present aturada. Així, s' hauran recorregut des de la parada anterior, uns $0^{\prime} 2 \mathrm{Km}$. Poc més o menys.

Tot aquest recorregut, s'haurà efectuat entre afloraments dels nivells esquistosos de I'Ordovicià, entre els quals es troben freqüents intercalacions de calcàries i de dolomies. Aquests materials s'inclouen dintre de la denominada Zona Axial, en la qual hem entrat en fer el recorregut cap a la parada anterior. En aquest indret, on efectuarem la present aturada, hi ha una interessant mineralització filoniana, la qual es troba encaixada entre els materials esquistosos de la Formació de Canavelles, la qual pertany a l'Ordovicià. (fotografia 7). 
Entre els minerals primaris presents, cal fer esment dels següents: ARSENOPOIRITA (molt abundant), CALCOPIRITA, GALENA (indicis), PIRITA, CALCITA i QUARS (molt abundant). Entre els minerals d'alteració, cal fer esment dels següents: GOETHITA (terrosa i limonítica), HEMATITES (també terròs), ATZURITA. MALAQUITA, ESCORODITA i MELANTERITA. Tanmateix, hi ha presència d'indicis de CERUSSITA i d'ANGLESITA. Finalment, cal parlar de la presència d'ARAGONITA, i de dendrites de PIROLUSITA.

En aquest indret, va haver-hi unes interessants explotacions dels minerals d'arsènic; però amb la idea d'extreure I'OR NADIU, el qual es trobava disseminat entre l'arsenopirita.

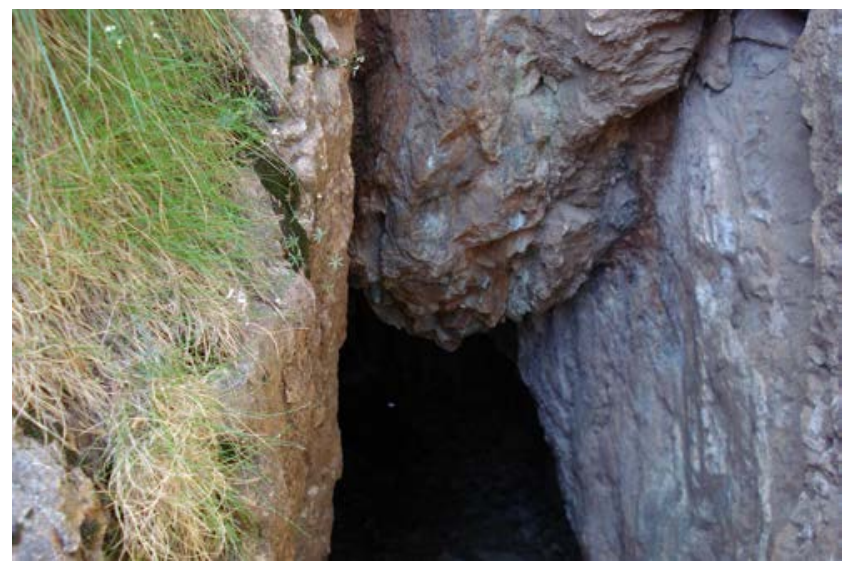

Fotografia 7. Bocamina de la Mina Saragossa. Vilamanya, terme de Queralbs

\subsection{Parada 8. PLA DE LES BARRAQUES, (terme municipal de Planoles, comarca del Ripollès). (Full 217).}

Des de la parada anterior, cal retornar enrere, fins a trobar la cruilla entre el camí - carreter procedent del poblet de Vilamanya i el que es dirigeix cap a Planoles. Seguint per aquest camí, arribarem a la carretereta que condueix cap al coll del Pla de les Barraques. En trobar-la, ens caldrà agafar-la. En arribar al coll farem una nova aturada, després de recórrer uns $10 \mathrm{Km} \mathrm{i}$ escaig, des de la parada anterior.

En tot aquest recorregut, s'han anat tallant els nivells esquistosos de l'Ordovicià. I aquests nivells són, precisament els materials que apareixen en aquest indret. Aquí, hi ha unes mineralitzacions filonianes, les quals no arriben a aflorar (en trobar-se cobertes pels derrubis de pendent). Tot i així, pot dir-se que aquests filonets encaixen entre els materials de la Formació Jujols, que són els que afloren en aquests indrets del coll.

Per d'altra banda, en aquest indret, van realitzar-se unes explotacions de les mineralitzacions anteriors, les quals es troben enrunades, per la qual cosa, tampoc són visibles les mineralitzacions a l'interior de les mines. (fotografia 8).

Entre els minerals primaris, els quals es troben a les escombreres, cal fer esment de la presència d'ARSENOPITA, CALCOPIRITA, ESTIBINA i PIRITA. També es troben la CALCITA, i sobretot el QUARS. Per d'altra banda, entre els minerals d'alteració, es troben: GOETHITA (terrosa i limonítica), HEMATITES (terròs, com I'anterior), ATZURITA, MALAQUITA, CALCANTINA, GUIX i MELANTERITA. 
Tanmateix es troben també indicis de CUPRITA i de TENORITA. També cal dir que hi ha presència de PIROLUSITA (dendrítica).

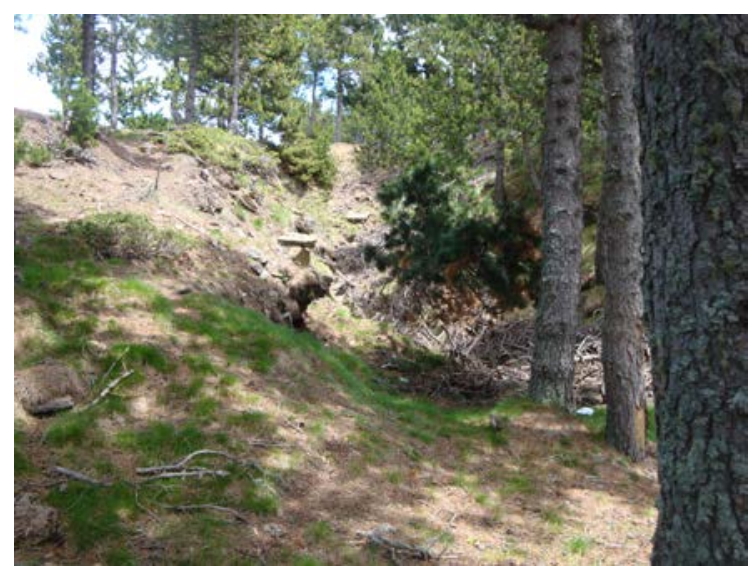

Fotografia 8. Zona Minera del Pla de les Barraques. Terme de Planoles

Per d'altra banda, des de l'indret on finalitza la carretera asfaltada, es pot gaudir d'una bona observació de la Vall de Queralbs. Fins i tot queden molt palesos els relleus del cim del Puigmal. (fotografia 9).

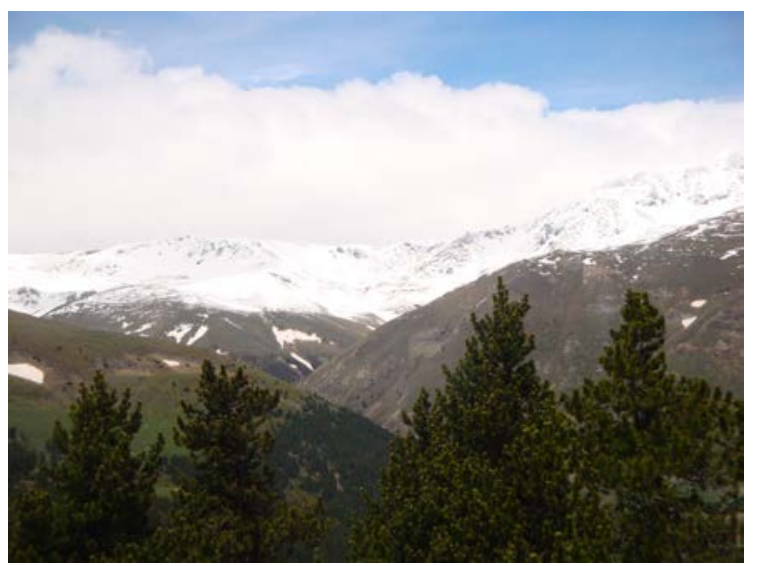

Fotografia 9. L'Alta vall de Queralbs i el Puigmal des del Pla de les Barraques. Terme de Planoles

En aquest indret finalitza el recorregut de l'itinerari. 


\section{Bibliografia}

GUIMERÀ, J. et altri (1992).- Geologia (II), Història Natural dels Països Catalans. Vol. 2, 547 pag. Enciclopèdia Catalana, S.A., Barcelona.

IGME (1991).- Mapa Geológico de España a escala 1:50.000 (síntesis de la cartografia existente). Full i memòria número 256 (Ripoll). Inst. Tecnol. y GeoMinero de España, Minist Indústria. Madrid.

IGME (1994).- Explicació del Mapa Geológico de España, a escala 1:50.000. Full i memòria número 255 (la Pobla de Lillet). Inst. Tecnol. y GeoMinero de España. Minist. Indústria. Madrid.

MATA-PERELLÓ, J.M. (1991).- Els Minerals de Catalunya. Arxius de la Secció de Ciències, t. XCIII, 442 pag. Institut d’Estudis Catalans. Barcelona.

MATA-PERELLÓ, J.M. (1995).- Recerca a través de la geografia física de set comarques de la Catalunya Central. Pub. Museu de Geologia de la UPC, 168 pàgines. Manresa.

MATA-PERELLÓ, J.M. (1996a).- Selecció d’itineraris geològics i mineralògics pel Berguedà, i per les seves comarques veïnes. Pub. Universitat Catalana d'Estiu de la Natura. 52 pàgines. Berga.

MATA-PERELLÓ, J.M. (1996b).- Itinerari geològico-mineralògic per les comarques del Ripollès i de la Garrotxa: des de Campdevànol a Olot i a les Preses. Inèdit, 12 pàgines, Manresa.

MATA-PERELLÓ, J.M. (1996c).- Recerca geològica i mineralògica per la comarca del Ripollès: des de Campdevànol a Sant Joan de les Abadesses, Surroca de Baix, Ribes de Freser i Planoles. Inèdit, 10 pàg. Manresa.

MATA-PERELLÓ, J.M. (1997a).- Recerca geològica i mineralògica pel Berguedà i pel Ripollès: des de Berga a La Nou i Malanyeu, i des de la Pobla de Lillet a Campdevànol. Inèdit, 9 pàgines. Manresa.

MATA-PERELLÓ, J.M. (1997b).- Recorregut de recerca geològica i mineralògica per les comarques del Berguedà i del Ripollès: des de la Pobla de Lillet a Castellar de N'Hug, a Ribes de Freser i a Queralbs. Inèdit. 10 pàgines. Manresa.

MATA-PERELLÓ, J.M. (1998).- Recerca geològica i mineralògica per la comarca del Ripollès: des de Campdevànol a Ribes de Freser, Queralbs i a Planés de Rigard. Inèdit. 11 pag. Manresa.

MATA-PERELLÓ, J.M. (2007).- Recerca geològica y mineralògica per la comarca del Ripollès: des de Campdevànol a Ribes de Freser, Queralbs, Planoles i Toses. Inèdit. 12 pag. Manresa.

MATA-PERELLÓ, J.M. (2011a).- Recerca geològica i mineralògica per la comarca del Ripollès: des de Campdevànol a Ribes de Freser, Queralbs, Planoles i a Toses. Inèdit. 11 pàgines. Manresa.

MATA-PERELLÓ, J.M. (2011b).- Recerca geològica i mineralògica per la comarca del Ripollès: des de Ribes de Fresser, al Serrat, a Vilamanya i a Queralbs. Inèdit. 8 pàgines. Manresa.

MATA-PERELLÓ, J.M. (2013a).- Recorregut de recerca geològica i mineralògica per la comarca del Ripollès: des de Ribes de Freser, a Rialb, al Serrat, Vilamanya i a Queralbs. Inèdit. 8 pag. Manresa.

MATA-PERELLÓ, J.M. (2013b).- Recerca geològica i mineralògica per la comarca del Ripollès: des de Ribes de Freser a Planoles, Espinosa i a Toses. Inèdit. 8 pag. Manresa. 
MATA-PERELLÓ, J.M. i FONT SOLDEVILA, J. (1995).- Itinerari geològic-mineralògic pel Berguedà. Apunts EUPM, 78 pag. Barcelona.

MATA-PERELLÓ, J.M. i SANZ BALAGUÉ, J. (1991).- Guia de determinació dels minerals. Països Catalans i Altres. Edic. Parcir. Manresa.

RIBA ARDERIU, O. Et altri. (1976).- Geografia física dels Països Catalans. Edit Ketres. Barcelona. 